\title{
STUDIES OF THE RATE OF DISAPPEARANCE OF LABELED THYROXINE FROM THE INTRAVASCULAR COMPARTMENT*
}

\author{
By EDWARD J. LENNON, NORMAN H. ENGBRING AND \\ WILLIAM W. ENGSTROM \\ (From the Department of Medicine, Marquette University School of Medicine and Milwaukee \\ County Hospital, Milwankee, Wis.)
}

(Submitted for publication June 23, 1960; accepted March 2, 1961)

The reversible combination of thyroxine with certain of the plasma proteins clearly provides an efficient transport mechanism enabling microgram quantities of the hormone to be carried to tissue sites with minimal losses via glomerular filtration and other nonselective excretory pathways. The demonstration of thyroxine-binding proteins in other extracellular fluids (1) and within cells (2) suggests a means by which thyroxine may be selectively distributed to tissues according to their individual needs.

The role, if any, of the plasma thyroxine-binding proteins in various thyroid disorders is not clear. In vitro studies of the protein-thyroxine complex involve alterations of $\mathrm{pH}, \mathrm{P}_{\mathrm{CO}_{2}}$, temperature and other aspects of the biochemical environment and may not give an accurate index of in vivo relationships. Furthermore, such studies neglect interactions of plasma thyroxine-binding proteins and extravascular thyroxine-binding proteins.

It seemed reasonable to suppose that the rate of disappearance of ${ }^{131}$-labeled L-thyroxine $\left(\mathrm{T}_{4}{ }^{*}\right)$ from the intravascular compartment during an acute experiment might yield information about the rate at which equilibrium between intra- and extravascular compartments was approached. The rate of disappearance should reflect the ability of the serum proteins to bind thyroxine and retain it within the vascular compartment in the face of all ambient forces favoring its removal. Conventional studies of labeled thyroxine survival (measured in days) are presumed to measure primarily the rate of thyroxine disposal after equilibration between labeled and stable thyroxine has been attained throughout the body. In preliminary studies, attempts were made to measure the rate

* This investigation was supported in part by Public Health Service Grants A-1200 and 2A-5023, National Institute of Arthritis and Metabolic Diseases, Bethesda, Md. of disappearance of $\mathrm{T}_{4}{ }^{*}$ from the circulation of isolated extremities but technical problems precluded accurate measurement. A whole-body technic was therefore employed and found to be satisfactory.

The method consisted in determining the rate of disappearance of $\mathrm{I}^{131}$-L-thyroxine from the intravascular compartment of human subjects during a 30-minute period after allowing 20 minutes from time of intravenous injection for thorough intravascular mixing. The unsteady state prevailing shortly after the injection of $\mathrm{T}_{4}{ }^{*}$ was deliberately selected for the period of study because the rate of loss of $\mathrm{T}_{4}{ }^{*}$ from the circulation is maximal at this time and the apparent volume of distribution is rapidly expanding. The rate of disappearance was calculated and was shown to be reproducible.

Experimental results indicate: a) a profound influence of the liver on the acute disappearance rate of $\mathrm{T}_{4}{ }^{*}$, indicated by a markedly prolonged intravascular retention of thyroxine in subjects with hepatic disease; $b$ ) rapid disappearance of $\mathrm{T}_{4} *$ in patients with diffuse toxic goiter (Graves' disease), but no significant change from normal in subjects fed large doses of desiccated thyroid, and slight prolongation of disappearance rate in subjects with toxic nodular goiter; and $c$ ) marked prolongation of disappearance rate in subjects with spontaneous myxedema, but no similar prolongation in subjects with Graves' disease who developed myxedema after treatment of hyperthyroidism.

\section{MATERIAL AND METHODS}

Each subject was evaluated by one or more of the authors and a clinical impression of the state of thyroidal function was made without reference to laboratory studies. Impressions were confirmed by serum protein-bound iodine (PBI) determinations and, in some instances, by measuring the thyroidal 24-hour uptake of $\mathrm{I}^{131}$. The 
control group consisted of 15 euthyroid subjects ranging from 13 to 76 years of age. None had clinical evidence of hepatic or renal disease, but some suffered from a variety of other nonfebrile illnesses, e.g., generalized arteriosclerosis, carcinoma of the lung, mild malnutrition, compensated heart disease, and so forth.

The study groups consisted of 9 euthyroid subjects with liver disease, 7 subjects with toxic nodular goiter, 9 with Graves' disease and thyrotoxicosis, 4 subjects with Graves' disease who had become euthyroid after treatment (one of these receiving 3 grains of desiccated thyroid daily because of moderate exophthalmos), 5 subjects with Graves' disease who were myxedematous as a result of treatment and 7 subjects with spontaneous primary myxedema. In addition, 10 subjects whose ranges of acute thyroxine disappearance rate approximated the ranges observed among the various groups were subjected to a second study 2 to 4 days after the initial measurement to estimate reproducibility of the method.

Subjects were brought to the radioisotope laboratory in the early afternoon without special preparation. A no. 18 needle was inserted and secured in an antecubital vein and connected to one limb of a Radicoil (Abbott) resting in a shielded well-type scintillation counter. The other limb of the Radicoil was connected via a three-way stopcock to a $20 \mathrm{ml}$ syringe and a solution of $50 \mathrm{mg}$ aqueous heparin in $500 \mathrm{ml}$ of isotonic saline. Blood was withdrawn through the Radicoil to the 10 $\mathrm{ml}$ mark of the syringe, counted for 1 minute, and reinjected into the subject. This step was repeated one or more times, depending on background radioactivity. At time zero, a 20 to $30 \mu \mathrm{c}$ dose of $\mathrm{T}_{4}{ }^{*}$ of high specific activity (Abbott) was injected into a vein in the opposite arm. The $T_{4}{ }^{*}$ was used within 7 days of delivery; it was not rechromatographed before use since prior studies indicated that free $\mathrm{I}^{131}$ had little influence on the function being measured. The three-way stopcock was adjusted to permit a slow drip of the heparin solution to prevent clotting in the indwelling needle. At 5-minute intervals, blood was drawn into the Radicoil, counted for 1 minute and reinjected. Care was taken to draw the blood slowly (20 seconds) to the $10 \mathrm{ml}$ mark of the syringe to prevent variations in mixing and dilution. Counting at 5-minute intervals was continued for 50 to 60 minutes after injection of the $\mathrm{T}_{4}{ }^{*}$. There was no significant adherence of thyroxine to the plastic Radicoil in the presence of plasma proteins.

\section{RESULTS}

When the curve of thyroxine disappearance is derived on semilog paper by plotting the net counts per minute (log scale) against time (linear scale), three distinct components of the curve are apparent. The first component, with most rapidly declining concentration of $\mathrm{T}_{4}{ }^{*}$, extends from 0 to 10 or 20 minutes after injection and primarily represents mixing and dilution of the $\mathrm{T}^{*}{ }^{*}$ within the vascular compartment. In normal subjects this brief, initial phase requires less than $10 \mathrm{~min}$ utes; however, when circulation is slowed, as in myexedma, it may extend to 20 minutes. Even in this brief period of mixing, simultaneous egress of $\mathrm{T}_{4}{ }^{*}$ from the circulation will occur, but it is not possible to separate that decline in radioactivity due to mixing from that due to extravascular movement. The moment when mixing is complete and when the decrements of $\mathrm{T}_{4}{ }^{*}$ largely represent egress from the circulation, cannot be ascertained.

The second component is curvilinear and extends for 1 or 2 days. It primarily represents mixing of $\mathrm{T}_{4} *$ throughout the body with establishment of an equilibrium between labeled and stable thyroxine. The curvilinear regression clearly represents the simultaneous operation of a number of processes: a) egress from the circulation-the rate of fall in plasma radioactivity by this function will be greatest when intravascular concentration of $\mathrm{T}_{4}{ }^{*}$ is highest, i.e., the early part of the curve; b) re-entry of $\mathrm{T}_{4} *$ into the circulation from the extravascular compartment-as extravascular concentrations of $\mathrm{T}_{4}^{*}$ slowly increase, the contribution to plasma radioactivity increases; $c$ ) superimposed is the third component of the curve-the disposal of thyroxine from the body.

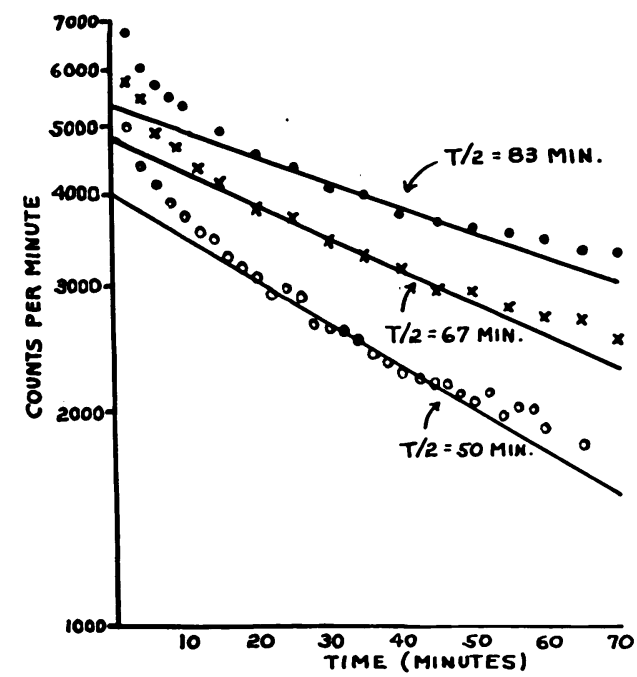

Fig. 1. Three illustrative curves plotted on SemiLOG PAPER SHOWING THE REGRESSION OF NET COUNTS PER MINUTE ON TIME AFTER INTRAVENOUS INJECTION OF $I^{131}$ L-THYroxine. ThE haLF-TIME VALUE IS DERIVED FROM CALCUlation OF THE SLOPE OF THAT SEgMENT OF THF CURVE BETWEEN 20 AND 50 MINUTES. 
TABLE I

Replicate determinations of acute thyroxine disappearance*

\begin{tabular}{lrrcc}
\hline \hline \multicolumn{5}{c}{$\begin{array}{c}\text { Acute thyroxine } \\
\text { disappearance rate } \\
\text { Half-time }\end{array}$} \\
\cline { 2 - 3 } Subject & $\begin{array}{c}\text { First } \\
\text { study }\end{array}$ & $\begin{array}{c}\text { Second } \\
\text { study }\end{array}$ & Difference & Difference \\
\hline & min & $\min$ & $\min$ & $\%$ \\
A.K. & 57.8 & 56.5 & -1.3 & -2.30 \\
R.B. & 43.9 & 44.1 & +0.2 & +0.46 \\
B.P. & 71.8 & 78.8 & +7.0 & +9.75 \\
E.K. & 96.5 & 88.3 & -8.2 & -8.50 \\
F.H. & 114.0 & 109.1 & -4.9 & -4.30 \\
C.B. & 65.4 & 68.1 & +2.7 & +4.13 \\
H.S. & 59.1 & 54.5 & -4.6 & -7.78 \\
F.T. & 123.4 & 103.8 & -19.6 & -15.88 \\
L.J. & 99.7 & 84.6 & -15.1 & -15.14 \\
L.B. & 55.6 & 63.5 & +7.9 & +14.21 \\
Mean & 78.7 & 75.1 & -3.6 & -2.5 \\
SD $\dagger$ & & & \pm 8.9 & \pm 9.9
\end{tabular}

* Second studies were performed 2 to 4 days after initial studies.

$\dagger$ Standard deviation.

The third component is practically linear and can be measured after equilibration is established (3). The normal half-time of thyroxine "survival" or disposal is about 6 days. Since the half-time is 3 or more days even in hyperthyroid states, the slope of this linear component, when considered over a 30 -minute period, is almost imperceptible and could influence calculated results very little.

Thus, while all of the above simultaneously occurring processes can not be separated, to obtain some measure or approximation of the net effect of forces favoring retention and removal of intravascularly injected (initially unbound) $\mathrm{T}_{4}{ }^{*}$, attention must be directed to the interval when $\mathrm{T}_{4}{ }^{*}$ concentrations are highest and decreasing most rapidly. While the mixing phase is rapid in normals, it may require as long as 20 minutes in some patients with myxedema. Therefore, so as to be able to compare different groups in a similar manner and since the "rate" was obtained by calculation rather than a visual fit, the regression from 20 to 50 minutes was chosen for analysis (Figure 1 and Table II). In this interval mixing should have been completed, re-entry of $\mathrm{T}_{4}{ }^{*}$ from extravascular spaces should be small although perhaps not insignificant in all circumstances, and

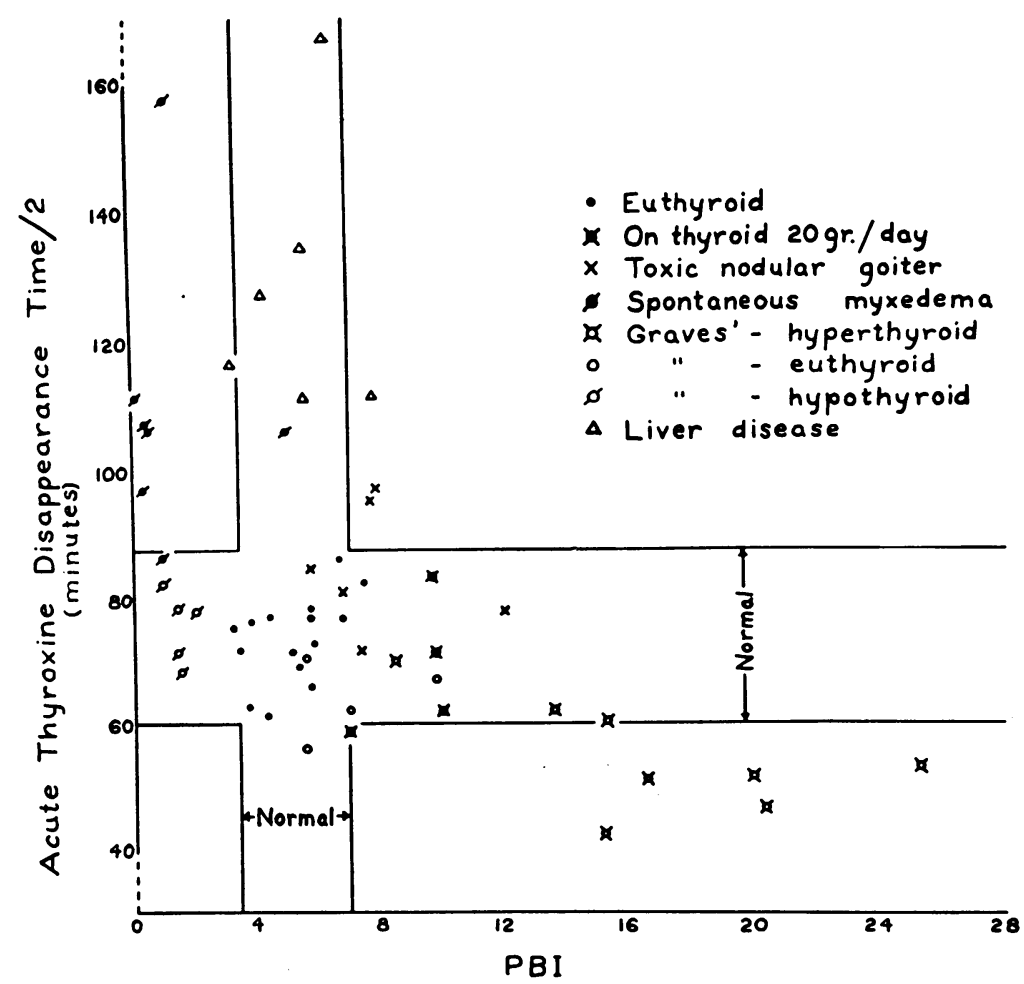

Fig. 2. The Relationship between PBI, Reflecting levels of thyroidal ACTIVITY, AND THE ACUTE THYROXINE DISAPPEARANCE RATE. 
THE ACUTE INTRAVASCULAR DISAPPEARANCE OF THYROXINE

TABLE II

Experimental results for control subjects and study groups

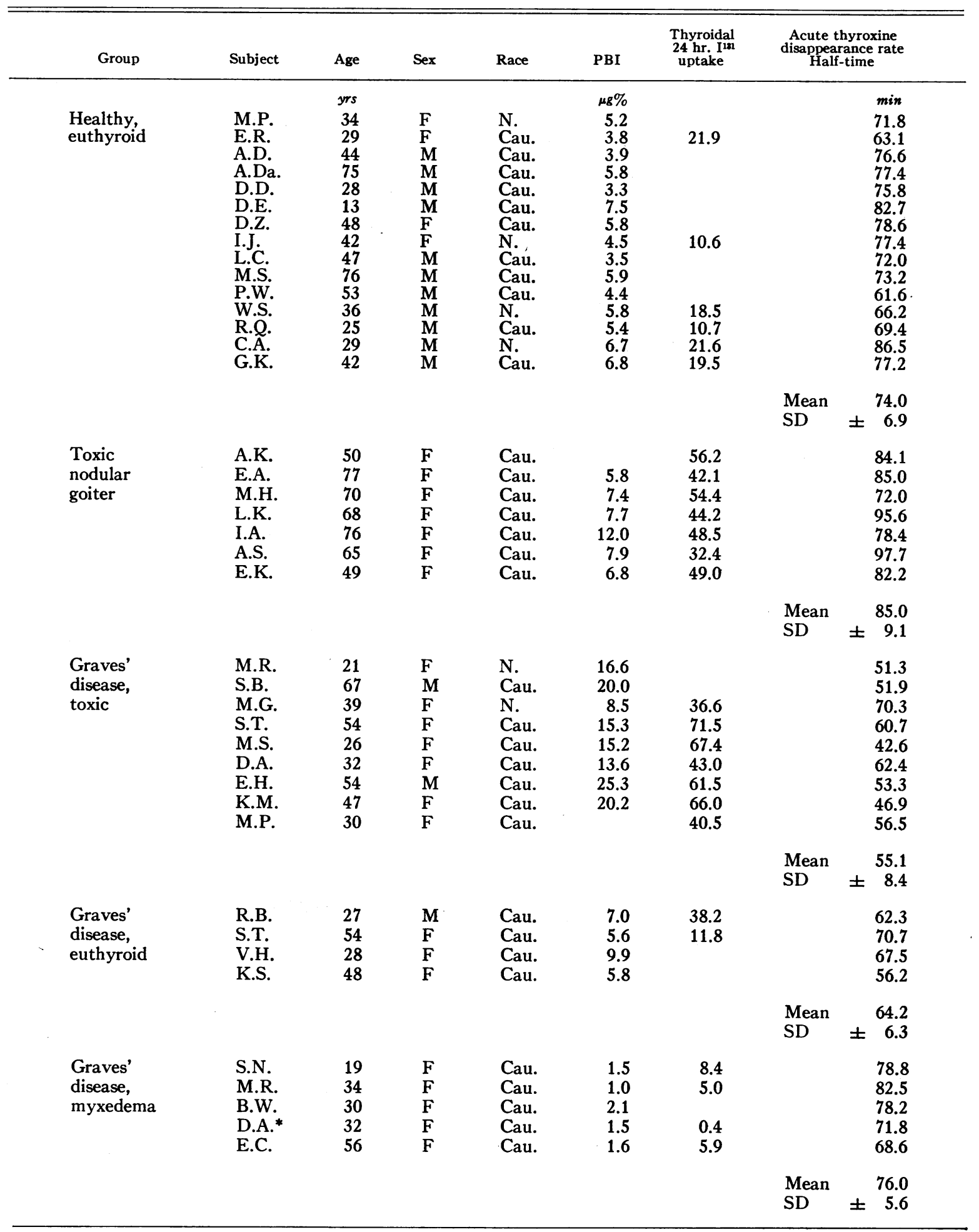

* Previously studied while thyrotoxic. 
TABLE II-(Continued)

\begin{tabular}{|c|c|c|c|c|c|c|c|c|}
\hline Group & Subject & Age & Sex & Race & PBI & $\begin{array}{l}\text { Thyroidal } \\
24 \text { hr II31 } \\
\text { uptake }\end{array}$ & $\begin{array}{r}\text { Acutet } \\
\text { disappea } \\
\text { Half }\end{array}$ & $\begin{array}{l}\text { yrroxine } \\
\text { ance rate } \\
\text { time }\end{array}$ \\
\hline \multirow[t]{2}{*}{$\begin{array}{l}\text { Spontaneous } \\
\text { primary } \\
\text { myxedema }\end{array}$} & $\begin{array}{l}\text { E.M. } \\
\text { G.E. } \\
\text { H.B. } \\
\text { C.D. } \\
\text { O.S. } \\
\text { M.B. } \\
\text { S.C. }\end{array}$ & $\begin{array}{c}y r s \\
71 \\
75 \\
69 \\
68 \\
59 \\
55 \\
85\end{array}$ & $\begin{array}{l}F \\
F \\
F \\
F \\
M \\
F \\
F\end{array}$ & $\begin{array}{l}\text { Cau. } \\
\text { Cau. } \\
\text { Cau. } \\
\text { Cau. } \\
\text { Cau. } \\
\text { N. } \\
\text { Cau. }\end{array}$ & $\begin{array}{l}\mu g \% \\
1.3 \\
3.0 \\
0.6 \\
0.5 \\
1.0 \\
0.4 \\
0.2\end{array}$ & $\begin{array}{l}2.4 \\
1.2 \\
3.2 \\
1.4 \\
4.3\end{array}$ & & \begin{tabular}{r}
\multicolumn{1}{c}{$\min$} \\
157.6 \\
106.4 \\
106.4 \\
107.5 \\
86.5 \\
97.1 \\
111.5
\end{tabular} \\
\hline & & & & & & & $\begin{array}{l}\text { Mean } \\
\text { SD }\end{array}$ & $\begin{array}{r}110.4 \\
+22.4\end{array}$ \\
\hline \multirow[t]{2}{*}{ Liver disease } & $\begin{array}{l}\text { J.H. } \dagger \\
\text { L.T. } \\
\text { R.L. } \\
\text { O.T. } \\
\text { A.W. } \\
\text { F.T. } \\
\text { M.W. } \\
\text { J.E. } \\
\text { M.B. }\end{array}$ & $\begin{array}{l}24 \\
43 \\
42 \\
42 \\
46 \\
48 \\
67 \\
44 \\
44\end{array}$ & $\begin{array}{l}M \\
M \\
M \\
M \\
F \\
M \\
M \\
M \\
F\end{array}$ & $\begin{array}{l}\text { Cau. } \\
\text { Cau. } \\
\text { Cau. } \\
\text { Cau. } \\
\text { N. } \\
\text { Cau. } \\
\text { Cau. } \\
\text { Cau. } \\
\text { N. }\end{array}$ & $\begin{array}{l}7.8 \\
4.3 \\
6.4 \\
5.6 \\
3.3 \\
5.6\end{array}$ & 15.4 & & $\begin{array}{r}111.9 \\
127.6 \\
250.9 \\
273.7 \\
135.0 \\
116.7 \\
111.5 \\
95.9 \\
248.8\end{array}$ \\
\hline & & & & & & & $\begin{array}{l}\text { Mean } \\
\text { SD }\end{array}$ & $\begin{array}{r}163.6 \\
\pm 71.8\end{array}$ \\
\hline \multirow[t]{2}{*}{$\begin{array}{l}\text { Normals } \\
\text { fed } \\
\text { thyroid }\end{array}$} & $\begin{array}{l}\text { W.S. } \\
\text { R.Q. } \\
\text { C.A. } \\
\text { G.K. }\end{array}$ & $\begin{array}{l}36 \\
25 \\
29 \\
42\end{array}$ & $\begin{array}{l}\mathrm{M} \\
\mathrm{M} \\
\mathrm{M} \\
\mathrm{M}\end{array}$ & $\begin{array}{l}\text { N. } \\
\text { Cau. } \\
\text { N. } \\
\text { Cau. }\end{array}$ & $\begin{array}{r}9.8 \\
7.0 \\
10.0 \\
9.7\end{array}$ & & & $\begin{array}{l}71.7 \\
59.0 \\
62.4 \\
83.8\end{array}$ \\
\hline & & & & & & & $\begin{array}{l}\text { Mean } \\
\text { SD }\end{array}$ & $\begin{array}{r}69.2 \\
\pm \quad 11.1\end{array}$ \\
\hline
\end{tabular}

$\dagger$ Studied during acute phase of infectious hepatitis.

the effects of thyroxine disposal from the body as a whole should be negligible. ${ }^{1}$

Statistical analysis indicated the probability that the portion of the curve for the relatively short 20 to 50 minute interval was linear in each case $(p<0.01)$. This linear portion of the regression curve was solved mathematically in each instance by the method of least squares and the slope was determined $(\log y=a+b x)$. The time required for the net counts per minute to decline to one-half the intercept value at time zero (time of injection of $\mathrm{T}_{4}{ }^{*}$ ) was obtained by extrapolation and is expressed as the "acute thy-

\footnotetext{
1 Our data, which does not contain simultaneously determined concentrations of extravascular $\mathrm{T}_{4}{ }^{*}$, does not permit the calculation of a precise rate constant for transfer of $T_{4}$ out of plasma, either in normals or in the different disorders studied. This would also require knowledge of the rate constant for transfer of $\mathrm{T}_{4}$ from the extravascular compartment to plasma. Thus, our results are expressed merely as a "rate," rather than a rate constant, and the slopes can not be considered to be true zero-time slopes.
}

roxine disappearance half-time." The statistical methods used were those described by Snedecor (4).

Replicate studies. To determine reproducibility in the same subject, ten subjects were restudied after 2 to 4 days without treatment. Subjects were selected on the basis of the first study to include the range of values noted within the study groups. Table I compares the results of first and second studies. The mean of the difference (first study minus second study) was -3.6 minutes. Group means for first and second studies were not statistically different $(\mathrm{p}>0.50)$.

Euthyroid controls. The acute thyroxine disappearance rate for 15 euthyroid controls was 74.0 minutes. Analysis of covariance indicated the likelihood of a common population regression coefficient for these subjects. Variations correlated with age, sex or race could not be detected in this relatively small group. Individual data for subjects in this and subsequent groups are given in Table II and in Figure 2. 
Liver disease. Marked prolongation of thyroxine disappearance rate was noted in the eight patients with Laennec's cirrhosis and in the one with acute infectious hepatitis. Details as to degree of hepatic involvement are given in Table III. The mean half-time of disappearance was $163.6 \mathrm{~min}$ utes. The slowest disappearance rates were observed in the subjects with ascites, indicating that expansion of the extracellular fluid volume need not accelerate disappearance rate (as might be expected if this measured simple diffusion from the intravascular compartment). The wide range of values observed undoubtedly reflects different degrees of hepatic impairment, but could not be correlated with any of the recorded indices of liver function. Difference from the control group was highly significant $(\mathrm{p}<0.001)$.

Hyperthyroidism. A sharp distinction between patients with nodular toxic goiter and those with diffuse toxic goiter (Graves' disease) was evident. The mean half-time of thyroxine disappearance for seven subjects with toxic nodular goiter (85.0 minutes) was actually significantly longer than that observed in the controls $(p<0.01)$. By contrast, nine patients with diffuse toxic goiter had a mean thyroxine disappearance half-time of 55.1 minutes, very significantly shorter than the control group ( $p<0.001)$.

In an effort to clarify this difference four healthy, euthyroid subjects were given increasing amounts of desiccated thyroid over a 6-week period, up to 20 grains daily. The thyroxine disappearance rate was determined at 2 -week intervals.
The results are summarized in Table II. As noted by others (5-7), the subjects tolerated large doses of thyroid well, although they manifested weight loss, slight tremor, increased sweating and mild tachycardia. The highest PBI value produced was $10.3 \mu \mathrm{g}$ per $100 \mathrm{ml}$. Mean thyroxine disappearance rate at the end of the experimental period (after 20 grains of desiccated thyroid had been administered daily for 1 week) was 69.2 minutes. This was not significantly different from the euthyroid control group $(p>0.40)$ or from the results in the same subjects before treatment with desiccated thyroid. None of the subjects had changes in disappearance rate falling outside the 95 per cent confidence limits for replicate studies in untreated subjects.

Myxedema and treated hyperthyroidism. Mean half-time of acute thyroxine disappearance for seven subjects with spontaneous, primary myxedema was 110.4 minutes, a highly significant difference from the control group $(p<0.001)$. When five subjects with Graves' disease were studied after they had become profoundly myxedematous from treatment, their thyroxine disappearance rate (mean half-time of 76.0 minutes) was very significantly longer $(p<0.001)$ than in hyperthyroid subjects with Graves' disease (mean half-time of 55.1 minutes), but not significantly different from that of euthyroid controls. Yet, interestingly, the disappearance half-time of 76.0 minutes was significantly shorter than in those with spontaneous myxedema (mean 110.4 minutes). Thus, although the development of myx-

TABLE III

Indices of hepatic function in subjects with liver disease

\begin{tabular}{|c|c|c|c|c|c|c|c|c|c|c|c|}
\hline Subject & Age & Sex & Race & Ascites & $\begin{array}{l}\mathrm{BSP} \\
\text { reten- } \\
\text { tion at } \\
45 \mathrm{~min}\end{array}$ & $\begin{array}{l}\text { Serum } \\
\text { albumin }\end{array}$ & $\begin{array}{l}\text { Pro- } \\
\text { throm- } \\
\text { bin } \\
\text { time }\end{array}$ & $\mathrm{Hgb}$. & $\begin{array}{c}\text { Choles- } \\
\text { terol }\end{array}$ & PBI & $\begin{array}{c}\text { Acute } \\
\text { thyroxine } \\
\text { disap- } \\
\text { pearance } \\
\text { rate } \\
\text { Half- } \\
\text { time }\end{array}$ \\
\hline & yrs & & & & $\%$ & $g \%$ & $\mathrm{sec}$ & $g$ & $m g \%$ & $\mu g \%$ & $\min$ \\
\hline L.T. & 43 & $\mathrm{M}$ & Cau. & + & 40.6 & 1.91 & 12.7 & 9.5 & 140 & 4.3 & 127.6 \\
\hline A.W. & 46 & $\mathrm{~F}$ & N. & 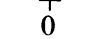 & $\begin{array}{l}40.0 \\
34.8\end{array}$ & $\begin{array}{l}1.91 \\
1.84\end{array}$ & 16.4 & 8.5 & 348 & $\begin{array}{l}4.0 \\
5.6\end{array}$ & 135.0 \\
\hline J.E. & 44 & $\mathrm{M}$ & Cau. & 0 & $\begin{array}{l}34.0 \\
31.4\end{array}$ & $\begin{array}{l}1.04 \\
3.15\end{array}$ & 19.0 & $\begin{array}{r}0.0 \\
10.0\end{array}$ & $\begin{array}{l}340 \\
100\end{array}$ & & 95.9 \\
\hline J.H.* & 24 & $\mathrm{M}$ & Cau. & 0 & 31.4 & $\begin{array}{l}5.15 \\
3.90\end{array}$ & 13.4 & $\begin{array}{l}10.0 \\
14.0\end{array}$ & 215 & 7.8 & 111.9 \\
\hline $0 . \mathrm{T}$ & 42 & M & Cau. & + & 42.8 & 3.60 & 13.4 & 7.0 & 308 & & 273.7 \\
\hline M.W. & 67 & $\mathrm{M}$ & Cau. & 0 & 41.0 & 2.42 & 15.6 & 9.0 & 130 & 2.6 & 111.5 \\
\hline F.T. & 48 & $\mathrm{M}$ & Cau. & 0 & & & $\begin{array}{l}10.0 \\
12.4\end{array}$ & 15.0 & & $\begin{array}{l}2.0 \\
3.3\end{array}$ & 116.7 \\
\hline R.L. & 42 & M & Cau. & + & $t$ & 2.30 & 24.6 & 10.5 & 133 & 6.4 & 250.9 \\
\hline M.B. & 44 & $\mathrm{~F}$ & Cau. & + & $t$ & 2.20 & 28.5 & 9.0 & 138 & & 248.8 \\
\hline
\end{tabular}

* Acute infectious hepatitis.

† Icteric, 
edema slows the disappearance rate, a specific difference in handling of labeled thyroxine seems to exist in Graves' disease even when functional thyroid tissue is absent, or virtually so.

Euthyroid Graves' disease. Four subjects with Graves' disease were studied when they were euthyroid after treatment. One of these (V.H.) was maintained on 3 grains of desiccated thyroid daily because of moderately severe exophthalmos (the elevated PBI noted in this case was attributed to extraneous iodine ingestion). Subjects had been euthyroid for from 3 months to 2 years. The group mean was 64.2 minutes and differed from the control group at marginal significance level $(\mathrm{p}<0.05)$.

\section{DISCUSSION}

The early phases of disappearance of intravenously injected $\mathrm{T}_{4}{ }^{*}$ from the circulation have not been studied in detail. Limited data from other sources $(3,8)$ and observations during the course of the present studies implicate a complex series of physiological events, many of which proceed simultaneously. These events include: $a$ ) mixing of $\mathrm{T}_{4}{ }^{*}$ within the intravascular compartment with almost immediate binding to the plasma proteins; b) distribution throughout the extrathyroidal thyroxine pool with intravascular-extravascular competition for $\mathrm{T}_{4}{ }^{*} ; c$ ) specific trapping of thyroxine by certain organs, particularly the liver; $d$ ) disposal of $\mathrm{T}_{4}{ }^{*}$ from the body via the gastrointestinal tract, by excretion of small amounts in the urine (8) and by metabolic degradation with subsequent appearance of free $\mathrm{I}^{131}$ in the blood, the thyroid and the urine. In the present studies, covering only a 30-minute period, it is unlikely that degradation of $\mathrm{T}_{4}{ }^{*}$ is significant since the total turnover of endogenous thyroxine does not appear to exceed 30 per cent per day even in hyperthyroid states (9). The present studies are believed to reflect primarily the events of $b$ and $c$ above, namely, the early distribution and specific trapping of thyroxine.

The half-time value determined from decreasing blood levels of radioactivity in each case reflects the rate at which equilibrium between labeled and stable thyroxine is being approached within the body. This process of equilibration is occurring at different rates between the intravascular and the many extravascular compart- ments of the body. The method of measurement employed in the present studies fails to distinguish between these various rates, but reflects them collectively. The technique intends only to estimate the balance existing between forces regulating the rate of removal of $\mathrm{T}_{4}{ }^{*}$ from the circulation. Although the calculated value does not represent a true rate constant, the results obtained were reproducible among groups of euthyroid individuals and among individuals with the various pathological states noted, and the results were statistically different between certain groups.

Factors which influence the acute rate of disappearance of a tracer amount of $\mathrm{T}_{4}{ }^{*}$ from the blood include: $a$ ) the relative size of intra- and extravascular thyroxine pools (e.g., a large intravascular pool of thyroxine would slow the rate of disappearance); $b$ ) the relative thyroxinebinding affinity and saturation of intra- and extravascular proteins (e.g., increased intravascular thyroxine-binding capacity would be associated with a slower rate of removal of $\left.\mathrm{T}_{4}{ }^{*}\right) ; c$ ) the integrity of the vascular lining which prevents extravasation of protein-bound $\mathrm{T}_{4}{ }^{*}$; and $d$ ) the ability of certain organs specifically to concentrate protein-bound or free $\mathrm{T}_{4}{ }^{*}$.

The relationship of intravascular protein binding of thyroxine to thyroidal economy in normal as well as in pathological states has received considerable attention. In vitro measurements of thyroxine-binding capacity permit comparison of the binding affinity of plasma proteins in normal and abnormal states under the conditions imposed by the technique of measurement. The effectiveness with which plasma proteins retain thyroxine within the circulation of intact subjects, however, must be equally dependent upon the relative binding affinity of extravascular proteins as well as upon the other factors mentioned above. The present studies suggest a reasonably good correlation between the rate of removal of thyroxine from the blood and in vitro estimates of plasma-binding capacity. In circumstances reported to exhibit increased thyroxine-binding capacity of the serum proteins, a delay in the acute disappearance of thyroxine from the circulation was observed, i.e., in seven patients with primary myxedema, in a single subject with acute hepatitis, and in subjects given diethylstilbestrol (unpublished observations). 
The findings in subjects with various types of hyperthyroidism are of particular interest. Subjects with Graves' disease, at all levels of thyroid function, had more rapid thyroxine disappearance rates than other subjects with comparable levels of metabolic activity. While it is clear, in comparing hyperthyroid, euthyroid, and hypothyroid subjects with Graves' disease, that hyperthyroidism has some influence on the function measured, the failure to find significant similar acceleration in subjects with toxic nodular goiter or in thyrotoxicosis medicamentosa suggests a more specific abnormality in Graves' disease. It may be argued that subjects with Graves' disease simply have a larger extravascular pool of thyroxine or that there was greater saturation of binding proteins (since PBI levels were somewhat higher in the Graves' group). However, the persistence of accelerated disappearance rate, in relation to others with comparable metabolic status, in Graves' subjects made hypothyroid, and probably also in those made euthyroid, invalidates this argument. Also, it is likely that those individuals with toxic nodular goiter and thyrotoxicosis medicamentosa had ample time to expand their extravascular thyroxine pools to a degree comparable to hyperthyroid Graves' subjects.

The data support the concept of a qualitative, biological difference between Graves' disease and toxic nodular goiter and suggest altered in vivo plasma or possibly even tissue protein binding of thyroxine in Graves' disease. Indeed, the abnormality is apparent when these patients have become myxedematous after treatment. In a preliminary report, Richards, Dowling and Ingbar (10) noted that thyroxine-binding by prealbumin is usually decreased in untreated thyrotoxic patients with Graves' disease, but a similar defect in subjects ill with other diseases was also observed. It may be that defective prealbumin binding of plasma in Graves' disease plays a significant role in the phenomena observed in the acute thyroxine disappearance rate. Our data and those of others do not exclude the possible importance of extravascular forces. Since we have not observed the acute thyroxine disappearance rate to be accelerated in illnesses other than Graves' disease, the defective prealbumin binding associated with some nonspecific illnesses may in turn be balanced by a comparable decrease in extravascular thyroxine- binding capacity. Certainly, patients with nonspecific illnesses do not exhibit signs of hyperthyroidism.

Our observations on acute thyroxine disappearance rate in Graves' disease are consonant with the increased thyroxine turnover rates in subjects with treated Graves' disease (11) and with the finding that heterologous serum labeled with $\mathrm{T}_{4}{ }^{*}$ disappears from the circulation in accordance with the recipient's thyroid status rather than the donor's (12). Also, Hamolsky, Ellison and Freedberg have shown that labeled thyroxine is more avidly incorporated by guinea pig diaphragm in vitro from sera of patients with Graves' disease than from sera of subjects with toxic nodular goiter or sera from normals enriched in vitro to hyperthyroid levels of PBI (13). By contrast, they found that labeled thyroxine mixed with sera from subjects with Graves' disease disappeared more rapidly from the circulation of recipient dogs than when mixed with sera from normals or subjects with toxic nodular goiter. This finding is not easily interpreted without knowledge of the relative binding affinity for thyroxine of $d o g$ and human serum or of dog's extravascular proteins. Their findings may reflect poorer thyroxine binding by Graves' plasma and represent distributional phenomena rather than peripheral metabolic factors.

The finding of an actual, although slight, prolongation of thyroxine disappearance rate in subjects with toxic nodular goiter may be due to expansion of intravascular pool size out of proportion to increase in turnover. It is equally possible that this prolongation is related to the increased age (although other older patients did not share this finding) or to minor impairment of hepatic function (clinically not apparent).

The acute thyroxine disappearance rate was consistently and markedly prolonged in subjects with cirrhosis of the liver; in most instances the disappearance rates were even longer than in patients with spontaneous myxedema. While increased binding of thyroxine by plasma globulins has been described in hepatitis where the PBI is often elevated (14), this seems unlikely in Laennec's cirrhosis. In the latter, the PBI is usually normal or even low, and increased red cell uptake of triiodothyronine in vitro has been reported (15). The latter finding has been attributed to 
decreased binding affinity by the serum proteins in this condition. If such is the case in most instances of cirrhosis, it would then seem that intravascular factors (e.g., the ability of the plasma proteins to bind thyroxine) are of much less importance than are extravascular phenomena in effecting the acute thyroxine disappearance rate in liver disease. Thus, the liver may play a more important role in the handling and metabolism of thyroxine than has generally been appreciated. Preliminary observations during these studies and observations by others (8) indicate that thyroxine rapidly accumulates in the liver. Since fecal excretion of organic iodine is small $(9,16)$, this must indicate that: $a$ ) thyroxine trapped by the liver is excreted in the bile and reabsurbed via the enterohepatic circulation; $b$ ) thyroxine is released to the circulation after hepatic trapping, free or in bound form; or $c$ ) the liver stores large amounts of thyroxine for its own metabolic needs. Quantitative data are not available to decide which of the possibilities might predominate in affecting the acute handling of thyroxine.

The results of the present studies are very similar to those recently reported by Peterson and Pierce (17) regarding the disappearance of cortisol, cortisone and corticosterone from the intravascular space. Alterations from normal in the rates of disappearance of these steroids were noted in cirrhosis, myxedema, thyrotoxicosis ${ }^{2}$ and after administration of estrogen to normal subjects. These qualitative changes were similar to those we have reported for $\mathrm{I}^{131}$-thyroxine.

\section{SUMMARY AND CONCLUSIONS}

1. A method is described for the determination of the rate at which equilibrium between intraand extravascular thyroxine pools is approached after intravenous administration of labeled thyroxine. This measurement, termed the "acute thyroxine disappearance rate" is accomplished during a 30 -minute period beginning 20 minutes after the intravenous injection of $\mathrm{I}^{131}$-labeled L-thyroxine.

2. Subjects with Graves' disease were found to have shorter acute thyroxine disappearance rates

\footnotetext{
2 By personal communication, we are informed that all of their patients with "thyrotoxicosis" suffered from Graves' disease.
}

at all levels of thyroid function than other subjects with comparable thyroidal activity. Even when functionally athyrotic, the patients with treated Graves' disease handled thyroxine differently from athyrotic subjects without Graves' disease. This observation suggests that plasma or extravascular protein binding of thyroxine in subjects with Graves' disease may be altered in vivo and that this alteration is not the direct result of hypermetabolism or hyperthyroidism.

3. No significant shortening of thyroxine disappearance rate was noted in patients with toxic nodular goiter or in normals fed exogenous thyroid. This finding indicates a qualitative difference between the toxic nodular goiter and Graves' disease. These observations cannot be accounted for by differences in the level of the PBI or derivatives of this measurement, since the thyroxine disappearance rate in Graves' disease remained relatively rapid after treatment of hyperthyroidism.

4. Greatly prolonged thyroxine disappearance rates in subjects with liver disease suggest that the liver plays an important role in the handling of thyroxine.

5. Replicate experiments indicate that the method of study is reproducible and applicable to the study of drug and hormone effects on the rate of egress of labeled hormone from the circulation.

\section{ACKNOWLEDGMENT}

It is a pleasure to acknowledge the technical assistance of Miss Virginia Griffin and Mrs. Marian Wisniewski and to thank Miss Griffin for reviewing the statistical analyses.

\section{REFERENCES}

1. Freinkel, N., Ingbar, S. H., and Dowling, J. T. The influence of extracellular thyroxine-binding protein upon the accumulation of thyroxine by tissue slices. J. clin. Invest. 1957, 36, 25.

2. Tata, J. R. A cellular thyroxine-binding protein fraction. Biochim. biophys. Acta 1958, 28, 91.

3. Haddad, H. M. Rates of $\mathrm{I}^{131}$-labeled thyroxine metabolism in euthyroid children. $\mathrm{J}$. clin. Invest. 1960, 39, 1590.

4. Snedecor, G. W. Statistical Methods Applied to Experiments in Agriculture and Biology, 5th ed. Ames, Iowa State College Press, 1956.

5. Johnston, M. W., Squires, A. H., and Farquharson, R. F. The effect of prolonged administration of thyroid. Ann. intern. Med. 1951, 35, 1008. 
6. Goldsmith, R., and Stanbury, J. B. The tolerance of patients with myxedema for thyroid. J. clin. Endocr. $1955,15,568$.

7. Danowski, T. S., Huff, S. J., Tarail, R., Wirth, P., Peters, J. H., Mateer, F. M., and Garver, K. Serum protein-bound iodine during ingestion of desiccated thyroid. J. clin. Endocr. 1952, 12, 1572.

8. Benua, R. S., Albert, A., and Keating, F. R., Jr. The metabolism of radiothyroxine in exophthalmic goiter. J. clin. Endocr. 1952, 12, 1461.

9. Ingbar, S. H., and Freinkel, N. Simultaneous estimation of rates of thyroxine degradation and thyroid hormone synthesis. J. clin. Invest. 1955, 34, 808.

10. Richards, J. B., Dowling, J. T., and Ingbar, S. H. Alterations in the plasma transport of thyroxine in sick patients and their relation to the abnormality in Graves' disease (abstract). J. clin. Invest. $1959,38,1035$.

11. Ingbar, S. H., and Freinkel, N. Studies of thyroid function and the peripheral metabolism of $\mathrm{I}^{131}$-labeled thyroxine in patients with treated Graves disease. J. clin. Invest. 1958, 37, 1603.

12. Levy, R. P., Kelly, L. W., Jr., Cooper, G. W., and Jefferies, W. McK. The volume of distribution and turnover of endogenously labelled hu- man thyroid hormone from euthyroid and hyperthyroid donors (abstract). J. clin. Invest. 1955, 34, 948.

13. Hamolsky, M. W., Ellison, H. E., and Freedberg, A. S. The thyroid hormone-plasma protein complex in man. I. Differences in different states of thyroid function. J. clin. Invest. 1957, 36, 1486.

14. Vannotti, A., and Béraud, T. Functional relationships between the liver, the thyroxine-binding protein of serum, and the thyroid. J. clin. Endocr. $1959,19,466$

15. Hamolsky, M. W., Golodetz, A., and Freedberg, A. S. The plasma protein-thyroid hormone complex in man. III. Further studies on the use of the in zitro red blood cell uptake of $\mathrm{I}^{131}$ - - -triiodothyronine as a diagnostic test of thyroid function. J. clin. Endocr. 1959, 19, 103.

16. Berson, S. A., and Yalow, R. S. Quantitative aspects of iodine metabolism. The exchangeable organic iodine pool, and the rates of thyroidal secretion, peripheral degradation and fecal excretion of endogenously synthesized organically bound iodine. J. clin. Invest. 1954, 33, 1533.

17. Peterson, R. E., and Pierce, C. E. The metabolism of corticosterone in man. J. clin. Invest. 1960, 39, 741. 